\begin{tabular}{|c|c|}
\hline DOI: http://dx.doi.org/10.12775/AUNC_ZARZ.2015.048 & ZARZĄDZANIE XLII - NR 4 (2015) \\
\hline za wersja złożona & ISSN (print) $1689-8966$ \\
\hline
\end{tabular}

Magdalena Raczyńska*

\title{
PROCESS MANAGEMENT IN PUBLIC ADMINISTRATION
}

\begin{abstract}
The article concentrates on issues of implementing the process management concept in public administration bodies. It presents the problems of applying the concept in public organisations, deriving from the barriers of using modern management concepts in that sector. Also, a selection of process maturity models is presented, including the model designed especially to measure the process maturity of public organisations, so the model that take into account the specific and complex conditions of their functioning.
\end{abstract}

Keywords: public organisations; process management in public organisations; process maturity models.

Klasyfikacja JEL: M10

\section{INTRODUCTION}

In dynamically changing and turbulent conditions of organisational environment, all organisations are forced to look for ways that help them improve their efficiency and effectiveness. The political and socio-economic changes in Poland resulted not only in market facilitation and modernisation of business organisations, but also in development of a need to improve management in the public sector. Dynamic changes in society also consti-

Adres do korespondencji: Magdalena Raczyńska, Uniwersytet Warmińsko-Mazurski w Olsztynie, Wydział Nauk Ekonomicznych, Katedra Organizacji i Zarządzania, ul. M. Oczapowskiego 4, 10-719 Olsztyn, e-mail: misiewicz.magdalena@gmail.com 
tute an impulse for making adaptions in public organisations ${ }^{1}$, as the society has begun to demand a new standard of public service provision. As a result, for many years now, numerous reforms have been implemented in public administration ${ }^{2}$, aiming at abandoning the traditional bureaucratic style and introducing new management concepts. The basis for the new approach to organisation and management of public organizations was the criticism of the traditional bureaucracy model, which resulted in popularisation of the so-called New Public Management (NPM). The idea of NPM introduced the belief that the public administration model focused on procedures needed to be replaced with a model that is result-oriented. For this purpose, public administration started to implement solutions used in business organisations [Mazur, 2005, p. 57-58]. These solutions are, among others: introduction of strategic and marketing management principles, measurements of the short- and long-term effects of operations conducted by public administration bodies, introduction of the quality assurance system, evaluation of public services customers' satisfaction and introduction of modern management concepts [Flieger, 2013, p. 68-69].

One way to improve functioning of public administration is to introduce the concept of process management [Wiatrak, 2006, p. 26]. Organisations perceive the process approach as the key area for their development, a way to achieve operational excellence, facilitating organisational involvement and cooperation of its members, as well as improving internal communication [Kalinowski, 2011, p. 173; Hawrysz, Hys, 2012, p. 54]. It is mainly achieved by restructuring the organisations along cross-functional processes, which results in increased effectiveness and efficiency [Gulledge, Sommer, 2002, p. 366].

Implementing some elements of process management concept in public organisations has been recognised first in Anglo-Saxon countries. For example, in 1990, when there were many business process reengineering (BPR) project undertaken in private sector in US, also the US government organisations went through the reform initiative named National Perfor-

1 Term "public organisation" is used interchangeably with term "public administration" and "public administration bodies" in the paper.

2 H. Izdebski and M. Kulesza define public administration as a set of actions, activities and organizing and implementing projects, undertaken for the implementation of the public interest (the common good) by different entities, bodies and institutions, on the basis of the law and defined by law forms [Izdebski, Kulesza, 2004, p. 93]. 
mance Review, which main intention was organisational change ${ }^{3}$ [Stemberger, Kovacic, Jaklic, 2007, p. 119]. Similar initiatives were undertaken in those days in UK, Canada or in New Zeland [Gulledge, Sommer, 2002, p. 373-374]. In Poland, one can also indicate the examples of implementation of process management concept's elements in public organisations. A good example is the introduction of the idea of electronic administration (e-government), an idea, which leads to rationalisation of employment (which in turn reduces operating costs of an organisation) by automating processes executed by public organisations. As a result, processes can be delivered more swiftly, what may lead to improving their effectiveness [Brodnicki, Kubiszewska, Tymszuk, 2012, p. 2-7]. An equally important project aimed at reforming public organisations by introducing elements of process management was the project "E-government as the requisite for the development of Poland", executed in the years 2010-2012 by the University of Warmia and Mazury. Throughout the duration of the project, data on processes were collected in the selected administration bodies, on the basis of the tasks being implemented, specified by legal regulations for public administration. Then, model solutions were prepared; they were used to build a benchmarking base, enabling improvement in public organisation management by comparing the course of own processes with the model processes [Sasak, 2013, p. 190]. Despite undertaking initiatives aiming at making public organisations in Poland process-oriented, a consistent methodology of full implementation of the process management concept in public administration bodies has not yet been developed, which is mainly determined by the existence of number of barriers hindering its implementation.

The purpose of this study is to present the issues of process management in public organisations, including the premises and barriers for application of the said concept in these organisations. Furthermore, the author discusses the term of process maturity of an organisation and presents selected models of its assessment, including the model that may be used for assessing process maturity in public administration bodies in Poland.

3 During the National Performance Review initiative, several process change methods like business process reengineering or its more progressive methods of continuous process improvements were used [Stemberger, Kovacic, Jaklic, 2007, p. 119]. 


\section{THE ISSUE OF IMPLEMENTING PROCESS MANAGEMENT CONCEPT IN PUBLIC ORGANISATIONS}

Business process management (BPM) is as old as the discipline of industrial engineering. The process management approach requires:

- Making process documentation to obtain an understanding of how work flows through the process,

- Assigning process ownership in order to establish managerial accountability,

- Managing the process to optimize the measures of process performance,

- Optimizing the process to enhance product quality or measures of process performance [Gulledge, Sommer, 2002, p. 364].

So whether in the private or public sector, process management approach involves the documentation, ownership, on-going management and constant improvement of the processes.

Process management in public organisations, in a nutshell, consists of making a public administration body process-oriented and is based on the assumption that its operation should be optimised, bearing in mind the processes occurring therein, and not its functions, as it used to be in the traditional administering style [Krukowski, 2011, p. 24].

The peak of the process management concept popularity in business organisations occurred roughly in the mid-1990s. Also at that time, the world began to notice the possibility of applying the concept in public administration, which was demonstrated by the emergence of the first publications dedicated to this concept in public organisations [Houy, Fettke, Loos, 2014, p. 627 ; Hawrysz, Hys, 2012, p. 56].

In the literature, there are several motives presented that drive the public sector to take a process view of its operations. For example, R. Tregear and T. Jenkins indicate the desire to make public services as digital as possible, creating new, lower cost delivery channels. The other key driver, according to the authors, is the desire to improve service levels ${ }^{4}$. Introduction of process management in public administration is also justified by the need for understanding the current needs of the citizens (customers), the ineffi-

4 Tregear R., Jenkins T., (2007) Government Process Management: A review of key differences between the public and private sectors and their influence on the achievement of public sector process management, Australia, http://www.w.bptrends.com/publicationfiles/1007-ART-Govt.ProcessMgt.-Tregear\%20and\%20Jenkins-ph.pdf [20.10.2015]. 
ciency of the functional approach, which consists in focusing on performing strictly defined procedures, and not on the actual customers' needs and the possibility of improving the operation of public administration offices, primarily as a result of their structures being more flexible, as well as their organisational order [Krukowski, 2011, p. 23; Gulledge, Sommers, 2002, p. 366; Flieger, 2012, p. 237].

Organisations do not become process-oriented overnight and it is clear that radical changes in the execution of business processes are not suitable for the public sector for many reasons, e.g. political or the reasons related to the organisational structures of public organisations ${ }^{5}$ [KucińskaLandwójtowicz, Kłosowski, 2012, p. 657; Stemberger, Kovacic, Jaklic, 2007, p. 119]. Despite the fact that, as it was already mentioned, making the structures of public organisations more flexible is seen as an opportunity for improving their operation, it is a very difficult task in the case of public administration bodies. These bodies do not usually have processor customer orientated structures ${ }^{6}$ but the hierarchical one, which hinders transfer of competences and horizontal information flow [Sasak, 2013, p. 193-194].

The organisational structure is not the only barrier for introduction of the process management concept to public organisations. In literature also some other obstacles are indicated. For example, legal and law limitations, the specific organisational culture, high number of rigid procedures, resistance to changes of the administration's employees, turbulent political environment and the lack of a consistent model of implementing the process management in public organisations [Krukowski, 2011, p. 28].

People are the factor, which is most commonly pointed out next to the organisational structure, when talking about the barriers of implementing process management in public sector. Organisation's employees represent an important component when realising an efficient process management concept. Due to the fact that in public administration there often a high level of work's division and specialisation exist, the knowledge about a certain process is concentrated in just a few employees. Due to

5 The implementation of business management concept requires time, above all, due to the fact that implementation of process management creates the need for abandoning the traditional hierarchical organisational structure, so popular in public organisations [Kucińska-Landwójtowicz, Kłosowski, 2012, p. 657].

6 Ahrend N., Walser K., Leopold H., Comparative Analysis of the Implementation of Business Process Management in Public Administration in Germany and Switzerland, http://ceur-ws.org/Vol-933/pap1.pdf [20.10.2015]. 
Fettke et. al, this situation may imply the following consequences: first, approaches to survey the process knowledge require high involvement of employees in order to set the process steps in detail, second, initiatives of reorganisation are often strictly limited or require special coaching because of a lack of necessary competencies. Also, even the implementation of a process organization in public administration bodies is complicated by the fact, that the responsible employees have to be convinced that a higher level of process orientation would be useful and would lead to better performance of the organization [Fettke, Zwicker, Loos, 2015, p. 497-498].

Usually, process management concept is implemented in public organisations during applying activities necessary to fulfil the certification requirements of ISO standards, which primarily constitute the requirement of identification and description of the organisation's main processes [Flieger, Kosiński, 2012, p. 301]. On the other hand, full implementation of process management involves the organisation passing through certain stages, which in the literature are classified as levels of process maturity of an organisation.

According to P. Grajewski, process maturity of an organisation is expressed as a range, in which the processes are formally: defined, managed, flexible, measured and effective [Grajewski, 2007, p. 119]. Process maturity can also be defined as a state, in which it is possible to repeatedly achieve the same result of processes, with a small margin of tolerance [Grela, 2013, p. 170]. One can say that in a process mature organisation all processes are identified and their effectiveness is analysed. Also in such organisations design of new processes is carefully planned and there is a clear division of roles and responsibilities in processes [Brajer-Marczak, 2012, p. 516; Flieger, Kosiński, 2012, p. 302].

Determination of the level of process maturity of an organisation requires a complex analysis of factors that determine implementation of the process management concept. Furthermore, the assessment of process maturity can be made using a number of diverse indicators, the comparative method (benchmarking), or a selected model of process maturity assessment. 


\section{ASSESMENT MODELS OF PROCESS MATURITY OF AN ORGANISATION}

The idea of process maturity assessment originates from the concept of total quality management (TQM), as well as the concept of business process management. Business Process Maturity Models (BPMM) typically include a sequence of levels (or stages) that form an anticipated, desired or logical path from an initial state to maturity [Röglinger, Pöppelbuß, Becker, 2012 , p. 3]. In consequence, they may also consist of sets of recommendations and good practices that enable organisations to reach operational efficiency of their processes. In most of the cases these models as a starting point determine the state of existing, on-going process (called as-is state), while their aim of application is to achieve a certain, future state of the process (called to-be state), often described trough maturity levels [Kalinowski, 2011, p. 230; Kalinowski, 2012, p. 174].

In literature there are many various kinds of process maturity assessment models described. The common base for the majority of these models has been the Capability Maturity Model (CMM). CMM origins from the works of W. Humphrey, who in 1989 described the first complex principle of assessing the process maturity of an organisation [Harmon, 2008, p. 1-2]. The Capability Maturity Model, after a series of modifications was transformed in 2002 into the Capability Maturity Model Integration (CMMI). This model is undoubtedly the most popular and common model of process maturity assessment of an organisation. However, it is worth noting that ca. 150 other models based on the CMMI model to various extents have been developed so far [Kalinowski, 2012, p. 175-179].

Levels of maturity in CMMI model are evaluated on a scale, distinguishing 5 basic levels of process maturity of an organisation (table 1).

CMMI model, although commonly used, is just one example of process maturity assessment models. Among other assessment models, which are worth mentioning, are e.g. Business Process Maturity Model (BPMM) and Process and Enterprise Maturity Model (PEMM).

The first of the cited models (BPMM), based on the $\mathrm{CMM}^{\text {model }}{ }^{7}$, has been developed by Object Management Group and is especially intended

7 Rosemann M., de Bruin T., Towards a business process maturity model, http:// eprints.qut.edu.au/25194/1/25194_rosemann_200601488.pdfhttp://eprints.qut.edu. au/25194/1/25194_rosemann_200601488.pdf [23.10.2015]. 
for organizations, which are interested or involved in improving business processes related to their products/services. The second model (PEMM) has been developed by Michael Hammer and is described as a useful process audit toolkit that helps organizations plan the process changes, track their progress and eliminate encountered obstacles. The model distinguishes the maturity assessed at the level of processes and the level of an enterprise [Kalinowski, 2011, p. 234].

Table 1. Levels of maturity in CMMI model.

\begin{tabular}{|c|l|}
\hline Maturity level & \multicolumn{1}{c|}{ Description } \\
\hline 1 & $\begin{array}{l}\text { At this level, the processes occurring in an organisation are incidental. } \\
\text { Therefore, the organisation is not aware that the activities performed } \\
\text { therein constitute processes. }\end{array}$ \\
\hline 2 & $\begin{array}{l}\text { At this level, the processes are replicable. Therefore, the organisation } \\
\text { is aware that the work proceeds in the form of processes, however, no } \\
\text { process documentation is kept. }\end{array}$ \\
\hline 3 & $\begin{array}{l}\text { At this level, the processes are identified and described, but not measu- } \\
\text { red. }\end{array}$ \\
\hline 4 & $\begin{array}{l}\text { At this level, the processes are identified, described and measured, but } \\
\text { not managed. }\end{array}$ \\
\hline 5 & $\begin{array}{l}\text { At this level, processes are identified, described and measured, but also } \\
\text { managed, which leads to their continuous improvement. }\end{array}$ \\
\hline
\end{tabular}

Source: Own work on the basis of Grela G., (2013), Ocena poziomu dojrzałości procesowej organizacji, "Nierówności społeczne a wzrost gospodarczy", Vol. 35, p. 176.

Although all the mentioned maturity models can be used regardless the sector, size or structure of organisations, sometimes the conditions of organisations' functioning are so complex and specific that the models cannot be used without their modifications. In literature, it is stated that the existing process maturity assessment models do not fully take into account the most important determinants of functioning of public administration in Poland, thus reliable and complex assessment of its process maturity level proves to be impossible. Identification of the determinants of process maturity of public organisations enables verifying the existing models of process maturity assessment, so that they can be useful for assessing the process maturity level of public administration. 
An example of an attempt to create an assessment model of process maturity of public organisations was a methodology of the Institutional Development Plan (Planowanie Rozwoju Instytucjonalnego - PRI), developed in the period of 2001-2004 in order to improve operation of local administration offices ${ }^{8}$. The PRI methodology is used to self-assess the condition of public administration body management, which at the same time enables easy programming of improvement actions. So far, it has been tested by a few dozen local authorities and has been assessed positively. It is still used by several local authorities to compare changes achieved as a result of improvement ${ }^{9}$.

According to the PRI methodology, municipal offices can reach five levels of process maturity. Assignment of a given office to a specific level of the PRI methodology depends on whether it meets particular criteria (table 2).

Table 2. Process maturity levels according to the PRI methodology.

\begin{tabular}{|l|l|}
\hline Maturity level & \multicolumn{1}{c|}{ Criteria } \\
\hline First & The office did not formally identify the processes. \\
\hline Second & $\begin{array}{l}\text { 1. The office identified the key processes, described their progress, } \\
\text { as well as formalised them in the form of an internal regulation. } \\
\text { 2. There are documents confirming selection of process owners. } \\
\text { 3. There are documents confirming that groups of office tasks, which } \\
\text { were identified as key processes, are performed in accordance with } \\
\text { the formally adopted description of their execution. }\end{array}$ \\
\hline Third & $\begin{array}{l}\text { 4. Most processes executed by the office were identified (not only } \\
\text { the processes crucial for its operation), moreover, their execution } \\
\text { was described and they were formalised in the form of an internal } \\
\text { regulation. } \\
\text { 5. There are documents confirming selection of process owners. } \\
\text { 6. There are documents confirming that the majority of processes } \\
\text { are performed in accordance with the formally adopted description } \\
\text { of their execution. } \\
\text { 7. There are documents confirming that the officials were trained with } \\
\text { regard to execution of processes in which they participate. }\end{array}$ \\
\hline
\end{tabular}

8 The consortium of Małopolska Szkoła Administracji Publicznej Uniwersytetu Ekonomicznego w Krakowie and the Canadian Urban Institute created the PRI method on behalf of MSWiA.

9 http://pri.msap.pl/index.php?option=com_content\&view=article\&id=49\&Item id $=37[25.10 .2015]$. 


\begin{tabular}{|l|l|}
\hline Maturity level & \multicolumn{1}{c|}{ Criteria } \\
\hline Fourth & $\begin{array}{l}\text { 8. Processes were identified, which require support of computer systems. } \\
\text { 9. Processes requiring computer support are actually executed with the use } \\
\text { of computer systems. } \\
\text { 10. Process execution monitoring system is in place, in the form of specific: } \\
\text { a) indicators and goals for performance of all processes, } \\
\text { b) inspection procedures performed by the process owners, } \\
\text { c) procedures of collection and analysis of executors' comments, } \\
\text { d) procedures of collection and analysis of process recipients' comments, and } \\
\text { it was approved in the form of an internal regulation. } \\
\text { 11. There are documents confirming that the processes are monitored accord- } \\
\text { ing to the adopted procedures and the binding indicator system. }\end{array}$ \\
\hline Fifth & $\begin{array}{l}\text { 12. Improvement mechanisms for process execution and establishment } \\
\text { of new processes are in place in case of: } \\
\text { a) changes in tasks performed by the office, } \\
\text { b) a need to achieve objectives adopted in the office strategies, } \\
\text { c) occurrence of other external factors, and they were approved in the form } \\
\text { of an internal regulation. } \\
\text { 13. There are documents confirming that the improvement mechanisms } \\
\text { of process execution and establishment of new processes are applied, with } \\
\text { the use of such tools, as: } \\
\text { a) process audits, } \\
\text { b) systematic self-assessment, } \\
\text { c) assessment and analysis of the achieved results, } \\
\text { d) comparison with processes established in other offices (process bench- } \\
\text { marking). }\end{array}$ \\
\hline
\end{tabular}

Source: Own work on the basis of Flieger M., (2012), Zarzadzanie procesowe w urzędach gmin. Model adaptacji kryteriów dojrzałości procesowej, Scientific Publishing House of the Adam Mickiewicz University, Poznań, p. 170.

Despite a relatively high practical usability, the PRI methodology is applied by only a few local governments. Also, no entity ensuring its relevance and further popularisation has been established ${ }^{10}$.

$10 \mathrm{http}: / /$ pri.msap.pl/index.php?option=com_content\&view=article\&id=49\&Item $\mathrm{id}=37$ [25.10.2015]. 


\section{CONCLUSION}

Organisations in Poland are increasingly becoming more process orientat$\mathrm{ed}^{11}$. With no doubt, the increasing knowledge about the benefits of implementing this concept in organisations may play here a big role.

Full implementation of process management, as well as measuring the level of process maturity of an organisation, is easier in the case of business organisations than in public ones. As it was pointed out earlier in this paper, the situation is related not only to the organisational structure of public administration bodies, but also, among others, to specific legal and regulatory conditions, which are difficult to change. Although the public sector has some limitations, one can indicate many attempts of introducing the concept to public organisations worldwide, and also in Poland (e.g. the idea of e-government and the project "E-government as the requisite for the development of Poland"). For sure undertaking these activities is clearly justified and they are assessed positively by public organisations' stakeholders and also by the society.

\section{LITERATURE}

Ahrend N., Walser K., Leopold H., Comparative Analysis of the Implementation of Business Process Management in Public Administration in Germany and Switzerland, http://ceur-ws.org/Vol-933/pap1.pdf [20.10.2015].

Brajer-Marczak R., (2012), Efektywność organizacji z perspektywy modelu dojrzatości procesowej, „Zarządzanie i Finanse”, nr 1, part 3.

Brodnicki K., Kubiszewska K., Tymszuk E., (2012), E-administracja w ujęciu jakościowym i finansowym, „Zarządzanie i Finanse”, nr 3, part 3.

Dojrzatość procesowa polskich organizacji. Podsumowanie II edycji badania dojrzałości procesowej polskich organizacji, (2013), http://procesowcy.pl/dojrzalosc2013.pdf [25.10.2015]

Fettke P., Zwicker J., Loos P., (2015), Business Process Maturity of Public Administration, [in:] vom Brocke J., Roseman M. (eds.), Handbook on Business

11 According to the report "Dojrzałość procesowa polskich organizacji", in 2013 there were $14 \%$ of organisations that reached the fifth level of process maturity (according to CMMI model), which is $2 \%$ more than in 2010 [Dojrzałość procesowa polskich organizacji, 2013, p. 10]. 
Process Management 2: Strategic Alignment, Governance, People and Culture, 2nd edition, Springer, New York.

Flieger M., (2013), Dojrzałość procesowa gmin w świetle badań wspótczesnych paradygmatów zarzadzania publicznego. Zastosowanie zarzadzania procesowego w urzędach gmin - wyniki badan,, „Przedsiębiorczość i Zarządzanie", Vol. XIV, nr 13, part 3.

Flieger M., (2012), Zarzadzanie procesowe w urzędach gmin. Model adaptacji kryteriów dojrzałości procesowej, Wydawnictwo Naukowe Uniwersytetu im. Adama Mickiewicza, Poznań.

Flieger M., Kosiński E., (2012), Orientacja na klienta organizacji procesowej $w$ dobie kryzysu zaufania - model satysfakcji. Studium przypadku organizacji sektora energetycznego, ,Zarządzanie i Finanse”, $\mathrm{nr} 4$, part 1.

Grajewski P. (2007), Organizacja procesowa, PWE, Warszawa.

Grela G., (2013), Ocena poziomu dojrzatości procesowej organizacji, „Nierówności Społeczne a Wzrost Gospodarczy”, nr 35.

Gulledge Jr T. R., Sommer R. A., (2002), Business process management: public sector implications, "Business Process Management Journal", nr 2.

Harmon P., (2008), Governance and Maturity, "Business Process Trends”, Vol. 1, nr 7.

Hawrysz L., Hys K., (2012), Procesowo zorientowana kultura organizacyjna w organizacjach sektora publicznego, „Edukacja Ekonomistów i Menedżerów. Problemy. Innowacje. Projekty", nr 4, part 26.

Houy C., Fettke P., Loos P., (2014), Empirical research in business process management- analysys of an emerging field of research, "Business Process Management Journal", nr 4.

Izdebski H., Kulesza M., (2004), Administracja publiczna. Zagadnienia ogólne, III Edition, Wydawnictwo Liber, Warszawa.

Kalinowski T., (2011), Modele oceny dojrzatości procesów, „Acta Universitatis Lodziensis", Folia Oeconomica 258.

Kalinowski T., (2012), Ocena stopnia wdrożenia zarzadzania procesowego w badanych przedsiębiorstwach, „Problemy Zarządzania”, Vol. 10, nr 2, part 37.

Kalinowski T., (2011), Business Process Maturity Assessment - Concept, Methods and Tools, "Acta Universitatis Lodziensis", Folia Oeconomica 257.

Krukowski K., (2011), Zarzadzanie procesowe w administracji publicznej, „Współczesne Zarządzanie”, nr 1.

Kucińska-Landwójtowicz A., Kłosowski M., (2012), Determinanty dojrzałości procesowej organizacji, ,Zarządzanie Przedsiębiorstwem”, Vol. IX.

Mazur S., (2005), Historia administracji publicznej, [w:] Hausner J. (ed.) Administracja publiczna, II Edition, Wydawnictwo Naukowe PWN, Warszawa. 
Rosemann M., de Bruin R., Towards a business process maturity model, http:// eprints.qut.edu.au/25194/1/25194_rosemann_200601488.pdfhttp://eprints. qut.edu.au/25194/1/25194_rosemann_200601488.pdf [23.10.2015].

Röglinger M., Pöppelbuß J., Becker Jorg, (2012), Maturity Models in Business Process Management, "Business Process Management Journal", nr 18, part 2.

Sasak J., (2013), Benchmarking procesów jako narzędzie doskonalenia administracji publicznej, [w:] Frączkiewicz-Wronka A. (ed.), Zarzadzanie publiczne. Koncepcje, metody, techniki, Wydawnictwo Uniwersytetu Ekonomicznego w Katowicach, Katowice.

Stemberger M. I., Kovacic A., Jaklic J., (2007), A methodology for increasing Business Process Maturity in Public Sector, "Interdisciplinary Journal of Information, Knowledge and Management", Vol. 2.

Tregear R., Jenkins T., (2007), Government Process Management: A review of key differences between the public and private sectors and their influence on the achievement of public sector process management, Australia, http:// www.w.bptrends.com/publicationfiles/10-07-ART-Govt.ProcessMgt.-Tregear\%20and\%20Jenkins-ph.pdf [20.10.2015].

Wiatrak A. P., (2006), Zarzadzanie w jednostkach sektora publicznego i jego uwarunkowania, [w:] Krukowski K. (ed.), Zarzadzanie organizacjami publicznymi, Uniwersytet Warmińsko-Mazurski w Olsztynie, Olsztyn.

http://www.pri.msap.pl/index.php?option=com_content\&view=article\&id=19\&Itemid $=27[25.10 .2015]$.

\section{PROCES ZARZĄDZANIA W ADMINISTRACJI PUBLICZNEJ}

Streszczenie: W artykule skoncentrowano się na kwestii wdrożenia koncepcji zarządzania procesami w organach administracji publicznej. Przedstawiono problematykę stosowania pojęcia $\mathrm{w}$ organizacjach publicznych, wynikających $\mathrm{z}$ bariery przy użyciu nowoczesnych koncepcji zarządzania w tym sektorze. Zaprezentowano również wybór modeli dojrzałości procesowej, w tym model zaprojektowany specjalnie do pomiaru dojrzałości procesowej organizacji publicznych, a więc modelu, który bierze pod uwagę specyficzne i złożone warunki ich funkcjonowania.

Slowa kluczowe: organizacje publiczne; zarządzanie procesami w organizacjach publicznych; modele procesu dojrzałości. 